\title{
Investigation of the Branched Chain Amino Acids Levels on Sportsmen Taking Colostrum Supplement by HPLC
}

\author{
Yalcin B1, Denli Z2*, Kivrak $\mathrm{A0}^{3}$ and Vatansev $\mathrm{H}^{1}$ \\ ${ }^{1}$ Department of Medical Biochemistry, Selcuk University, Faculty of Medicine, Turkey \\ 2Department of Medical Biochemistry, KTO Karatay University, Faculty of Medicine, \\ Turkey \\ ${ }^{3}$ Department of Sports Sciences, Selcuk University, Faculty of Health Sciences, Turkey
}

\section{Research article \\ Volume 3 Issue 5}

Received Date: October 15, 2018

Published Date: December 11, 2018

DOI: $10.23880 / \mathrm{ijbp}-16000143$

*Corresponding author: Zeynep Denli, Department of Medical Biochemistry, KTO Karatay University, Faculty of Medicine, Konya, Turkey, Email: zeynepdenli@gmail.com

\section{Abstract}

Colostrum secreted by female mammals immediately after birth is different from the normal milk secretion in terms of composition and appearance and its nutritional value is high. Colostrum has more essential amino acids and branched chain amino acids than daily milk. It was reported that athletes' physical performance and muscle development increase when they take colostrum supplement. The aim of this study is to investigate the changes of the branched-chain amino acid levels in sportsmen taking colostrum supplement. Total 48 sportsmen, 24 of them is in the experimental group and the rest is in the control group, participated in this study. Sportsmen in the experimental group have taken colostrum tablets $\left(250 \mathrm{mg} /\right.$ day). Blood samples were collected three times ( $0^{\text {th }}$ day, $30^{\text {th }}$ day, $60^{\text {th }}$ day). Their branched-chain amino acid levels were analyzed using the high-pressure liquid chromatography (HPLC) method. Statistical analysis was performed and comparisons between the experimental and control groups were evaluated.

Keywords: Bovine colostrum supplement; Branched-chain amino acids; HPLC; Sportsmen

\section{Introduction}

Colostrum is the first natural food for the new-born calf. It is secreted during the first few days after calving. Colostrum is not only a source of nutrients such as proteins, carbohydrates, fat, vitamins and minerals, but it also contains several biologically active molecules which are essential for specific functions [1]. Research with various mammalian species has identified a number of peptide growth factors, including insulin, IGF-I, and epidermal growth factor, that are present in higher concentrations in colostrum than in mature milk or formulas [2,3]. Given the anabolic nature of these growth factors, the prevailing hypothesis has been that their ingestion in colostrum enhances protein synthesis, thereby resulting in increased protein accretion and tissue growth, especially of the gastrointestinal tissues [4]. Bovine colostrum has important roles in efficient treatments of various diseases among persons. Its antioxidant and anti-aging characteristics help to 


\section{International Journal of Biochemistry \& Physiology}

overcome several problems age brings. Colostrum also supports recoveries from various mucosal, skin and muscle injuries [5]. Colostrum is so rich in nutrients; furthermore, it is known to involve many biologically active items effective on specific functions. For this reason, it is a foodstuff which protects health with its effects such as strengthening the immune system, encouraging cell development and repairing tissues [6].

When it is compared the content of colostrum with normal milk, it is shown that colostrum is a richer source in terms of essential amino acids and branched-chain amino acids. In comparison with the branched-chain amino acids in normal milk, it was seen that the level of valine is four-fold higher and the level of leucine and isoleucine is three-fold higher in colostrum [7].

In athlete's diet, protein intake is so important for muscle and body development. Recently, colostrum is used by especially athletes as a good protein source and a factor reducing stress and supporting the immune system. In this study, we aimed to investigate the effect of colostrum on the sportsmen's branched-chain amino acid levels and to show three amino acid levels (valine, leucine, and isoleucine) together into one chromatogram with the HPLC method.

\section{Materials and methods}

\section{Chemicals}

Phthaldialdehyde for fluorescence (79760), 3Mercaptopropionic Acid (63768), Sodium acetate trihydrate (S86259), Ethylenediaminetetraacetic acid (E9884), Lithium Citrate Hydrate (213209-500), L-Valine Standard (V0500-25), L-Leucine Standard (L8000-25), LIsoleucine Standard (I2752-25) and L-Norvaline Standard (N7627-5) were purchased from Sigma-Aldrich (St. Louis, MO, USA). Boric Acid (M100165.0500), HPLC Grade Water (M115333.2500), Methanol (M106007.2500), Acetic Acid (M100056.2500), 2-Propanol (M101040.2500), Sulphosalicylic Acid (SSA) (M800691.0250), Citric Acid Monohydrate (M100244.1000) and Sodium Hydroxide (M06498.1000) were obtained from Merck (Darmstad, Germany).

\section{Research Group}

In this research, 48 students at the School of Physical Education and Sports in Selcuk University voluntarily participating were divided into control and experimental group equally. All sportsmen were checked up at the Selcuklu Medicine Faculty Hospital in Selcuk University and their blood analyses, EKG and chest x-rays results were evaluated. The sportsmen who were not appropriate for the study were excluded. In the control group, it is not given any substance to sportsmen and they performed their training and diet program. In the experimental group, it is given one bovine colostrum capsule (250 mg/day) 2 hours after breakfast.

Bovine colostrum capsule is made by GNC company and is permitted by the Republic of Turkey Ministry of Food, Agriculture and Livestock (17.02.2009, Permission number: 906000285).

In order that the parameters analyzed in the research were not affected, the sportsmen were subjected to standard training and diet program. In the first day, $30^{\text {th }}$ day and $60^{\text {th }}$ day, it is done blood analyses of them. After centrifuged the blood of the sportsmen, serum samples were collected and stored at $-80{ }^{\circ} \mathrm{C}$. Branched-chain amino acid analyses were performed after solved at the room temperature in the experiment day. All measurements were done in a laboratory environment at $0^{\text {th }}, 30^{\text {th }}$ and $60^{\text {th }}$ day and completed in 60 days.

\section{HPLC Analyses}

The use of HPLC for amino acid analysis has been ongoing for more than 30 years. It has resulted in applications that are faster, more reproducible, and more sensitive than the classical Amino Acid Analysis (AAA) approach [8]. HPLC analyses for valine, leucine, and isoleucine amino acids were performed according to the Duran M, et al. [9].

In this study, norvaline was used instead of carboxymethyl cysteine as an internal standard because it was similar to valine structurally and only branchedchain amino acids were analyzed. Quantitative analyses were performed until it was determined a suitable dose for norvaline. In this step, the quantity and the presence of a peak of internal standard were important as a result of the same processes.

In the analysis, we observed that the orthophthalaldehyde (OPA) that is the reagent of choice for derivatization interfered with amino acid peaks and raised these peak areas. Because OPA did not interfere with amino acid peaks, we found a suitable dose by trying various OPA doses. Besides, we tried to find a suitable sample dose by mixing with suitable OPA dose and decreased sample volume. After the advised sample and OPA dose by Duran M, et al. had been reduced by half, it was obtained ideal peaks. According to Duran' method, it had been used 2-mercaptoethanol to prepare OPA. In this study, it was used 3-mercaptopropionic acid instead of 2- 


\section{International Journal of Biochemistry \& Physiology}

mercaptoethanol in order to increase the stability of OPA. Also, it was used borate buffer instead of potassium buffer recommended for preparing OPA. It was suggested that borate buffer was suitable for mobile phase because of being a more acidic buffer. In this process, we observed that liquids having equal $\mathrm{pH}$ were soluble in each other and were absorbed into the column.

In the process of sample preparation, according to Duran's method SSA dose used to precipitate proteins was recommended as $5 \%$ but in the study, we observed that this dose was not sufficient for precipitating proteins. It was prepared SSA at different doses. At the process of sample preparation, these doses were tried. The dose was increased until disappearing yellow color occurring at blood serum after centrifuge. It was determined that the most suitable SSA dose for precipitation of proteins was $35 \%$. More than 35\% SSA dose affected the analyses because of increasing the acidity of the sample.

The gradient used HPLC analyses is one of the most important steps in order to be able to resolve exactly. Gradient conditions depend on the laboratory environment, used mobile phase and $\mathrm{pH}$ of the medium. One of the mobile phases used was sodium acetate buffer and another organic solvent (methanol).

Since branched-chain amino acids are neutral amino acids, they appear towards the end of the chromatogram. Thus while it was being adjusted gradient, the ratio of acid buffer was decreased and the amount of the organic solvent increased. In the end, neutral amino acids, especially branched-chain amino acids, dissociated at the column and were appeared their peaks clearly.

Valine, Leucine and Isoleucine Analyse Method: The levels of valine, leucine, and isoleucine were analyzed using a gradient pump. It was prepared mobile phase A and $\mathrm{B}$ as gradient mobile phase.

\section{Preparation of Mobile Phase A}

Sodium acetate stock solution; sodium acetate trihydrate $(68.04 \mathrm{~g})$ and EDTA $(187.5 \mathrm{mg}$ ) were solved in $500 \mathrm{ml}$ HPLC grade water. Sodium acetate stock solution $(5 \mathrm{ml})$ was solved in $500 \mathrm{ml}$ HPLC grade water and added $50 \mathrm{ml}$ methanol and adjust to $\mathrm{pH}=5.75$ with an acetic acid solution.

\section{Preparation of Mobile Phase B}

$10 \mathrm{ml}$ isopropanol and $50 \mathrm{ml}$ HPLC grade water were added to $500 \mathrm{ml}$ methanol. Prepared mobile phase B was filtered by using $0.45 \mu$ filters. The degase procedure was made with an ultrasonic water bath.

\section{Preparation of Valine, Leucine, and Isoleucine Standards}

Valine, leucine, and isoleucine stock solutions $(1000$ $\mu \mathrm{M}$ ) is prepared in $0.1 \mathrm{~N} \mathrm{HCl}$ and stored in the refrigerator. From prepared $1000 \mu \mathrm{M}$ stock solutions, serial dilution with $0.1 \mathrm{~N} \mathrm{HCl}$ was made to $500 \mu \mathrm{M}, 250 \mu \mathrm{M}$, $125 \mu \mathrm{M}, 62.5 \mu \mathrm{M}, 31.25 \mu \mathrm{M}$, and $15.625 \mu \mathrm{M}$. After derivatization function, prepared standards were injected $20 \mu \mathrm{l}$ to the automatic sampling device. Standard curves were created for valine, leucine, and isoleucine with taken peak areas.

In this study, norvaline was used as an integral standard. $1000 \mu \mathrm{M}$ norvaline stock standard solution was prepared in $0.1 \mathrm{~N} \mathrm{HCl}$ and stored in the refrigerator.

\section{Preparation of Lithium Citrate Buffer}

Lithium citrate $(1,124 \mathrm{~g})$ was dissolved in deionized water and adjusted to $\mathrm{pH}=3$ with a citric acid solution.

\section{Preparation of Samples}

Serum samples stored at $-80{ }^{\circ} \mathrm{C}$ until experiment day were dissolved at room temperature. On $300 \mu \mathrm{l}$ serum sample, $50 \mu \mathrm{l}$ norvaline $(1000 \mu \mathrm{M})$ and $50 \mu \mathrm{l}$ sulfosalicylic acid (35\%) were added and incubated at 2-8 ${ }^{\circ} \mathrm{C}$ temperature during 30 minutes. It was centrifuged at $10000 \mathrm{x} \mathrm{g}$ for 10 minutes $\left(+4^{\circ} \mathrm{C}\right)$. After deproteinization, it was taken $150 \mu \mathrm{l}$ from the supernatant and added to $150 \mu$ lithium citrate buffer. Then valine, leucine, and isoleucine analyses were performed.

\section{Derivatization}

Standards and samples were derivated by using ophthalaldehyde (OPA). For derivatization, $25 \mathrm{mg}$ OPA was dissolved in $0.5 \mathrm{ml}$ methanol and $4.5 \mathrm{ml} 0.1 \mathrm{M}$ borate buffer $(\mathrm{pH}=10)$. Then $25 \mu \mathrm{L} 3$-mercaptopropionic acid was added to the prepared solution. Since the stability of the prepared derivatization solution was 2 days, it was prepared fresh before each analysis. Thanks to the injection program at HPLC system, $20 \mu \mathrm{L}$ sample supernatant and $10 \mu \mathrm{L}$ OPA solution were mixed and the mix was put into HPLC system after 1 min.

After analyses, the value of valine, leucine, and isoleucine in the samples measured by using peak areas according to their standard curves.

\section{Pump \\ Gradient mobile phase was used. Mobile phase A and B $(0.400 \mathrm{ml} / \mathrm{min}$.) were pumped to the system (Table1).}




\section{International Journal of Biochemistry \& Physiology}

\begin{tabular}{|c|c|c|}
\hline Time (min.) & A (\%) & B (\%) \\
\hline 0,0 & 95 & 5 \\
\hline 0,1 & 95 & 5 \\
\hline 8 & 90 & 10 \\
\hline 25 & 65 & 35 \\
\hline 40 & 40 & 60 \\
\hline 41 & 0 & 100 \\
\hline 43 & 95 & 5 \\
\hline 50 & 95 & 5 \\
\hline
\end{tabular}

Table1: Flowchart of mobile phase (Flow rate 0,400 $\mathrm{ml} / \mathrm{min}$ ).

\section{Detection}

Fluorescence detector was adjusted to $330 \mathrm{~nm}$ for excitation and $450 \mathrm{~nm}$ for emission. Agilent 1200 series HPLC system, $150 \mathrm{~mm} \times 4,6 \mathrm{~mm} \times 5 \mu \mathrm{m}$ Agilent eclipse column, guard column, and fluorescence detector were used. The total analysis time was limited to $50 \mathrm{~min}$.

\section{Statistical Analysis}

For statistical evaluations, the SPSS 15 statistical package program was used. Whether values were appropriate for normal distribution or not was detected with Kolmogorov-Smirnov test. According to the test result; it was seen that all values were appropriate for normal distribution. Then it was made paired sample ttest as a parametric test. Because of the comparison of the group using colostrum or not it was made independent sample t-test. It was accepted that the significant value is $\mathrm{p}<0.05$.

\section{Results and Discussion}

\section{Valine Standard Analysis}

It was determined that retention time for valine was 35.15 min. Chromatogram of valine standard was shown in Figure 1.

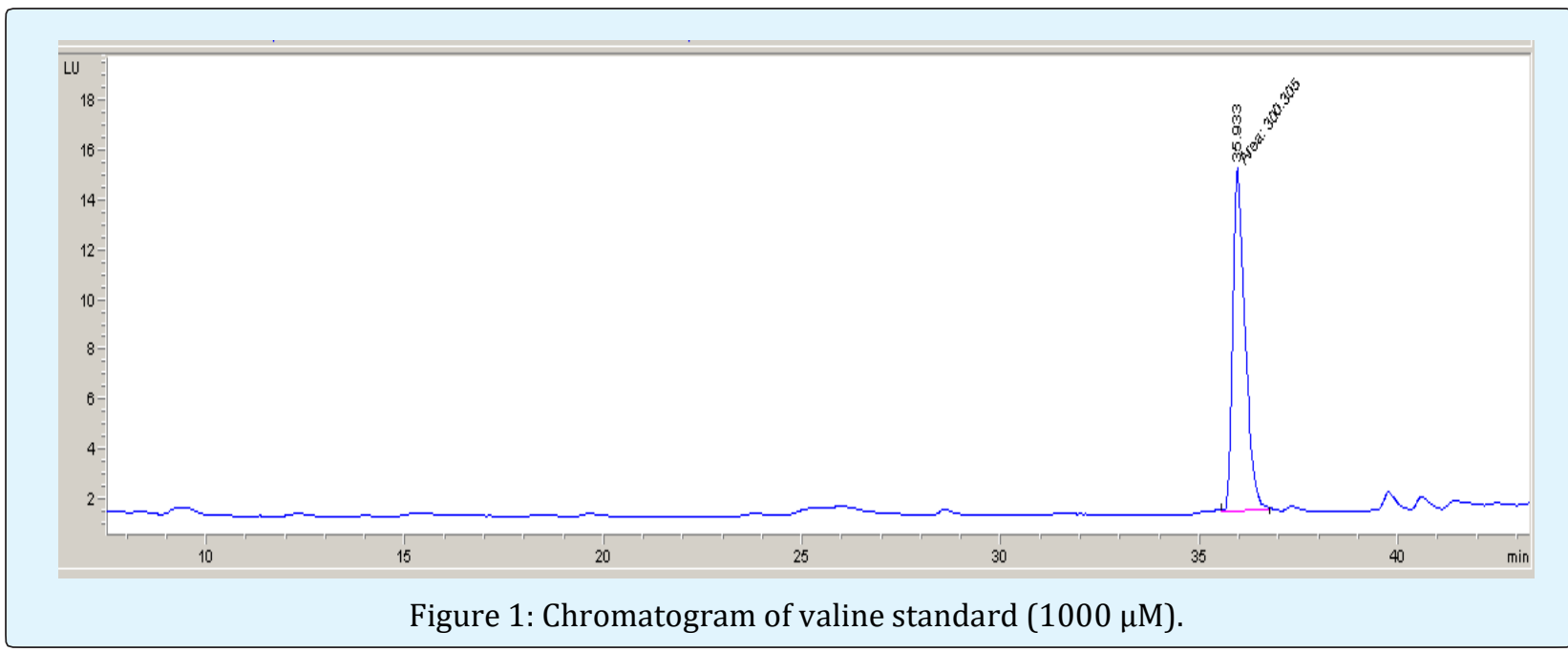

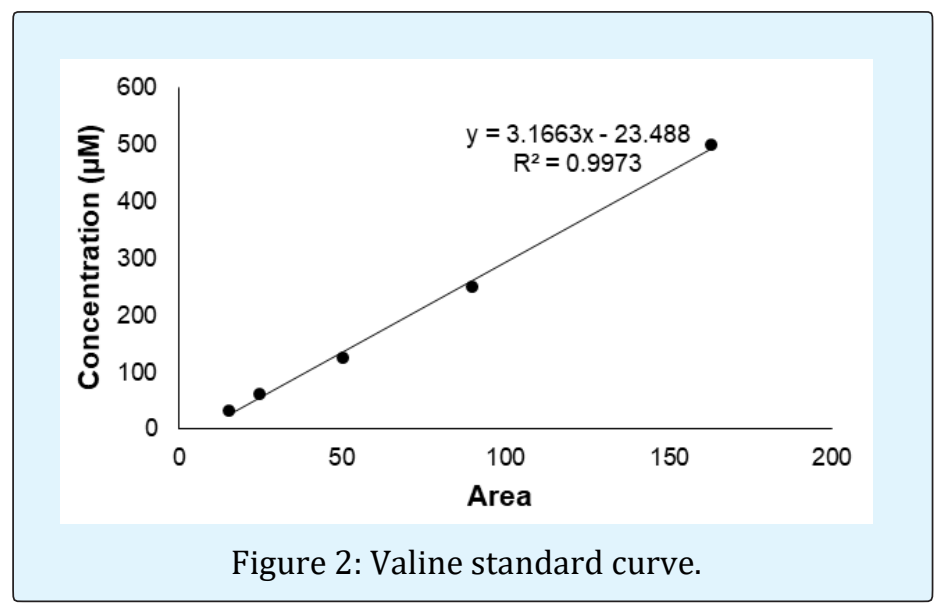

Denli Z. Investigation of the Branched Chain Amino Acids Levels on Sportsmen Taking Colostrum Supplement by HPLC. Int J Biochem Physiol 2018, 3(5): 000143.

\begin{tabular}{|c|c|}
\hline Concentration $(\boldsymbol{\mu M})$ & Peak Area \\
\hline 31,25 & 15,28 \\
\hline 62,5 & 24,76 \\
\hline 125 & 50,20 \\
\hline 250 & 89,87 \\
\hline 500 & 162,94 \\
\hline
\end{tabular}

Table 2: Peak areas corresponding to valine concentration $(\mu \mathrm{M})$.

\section{Leucine Standard Analysis}

It was determined that retention time for leucine was 39.66 min. Chromatogram of leucine standard was shown in Figure 3. 


\section{International Journal of Biochemistry \& Physiology}

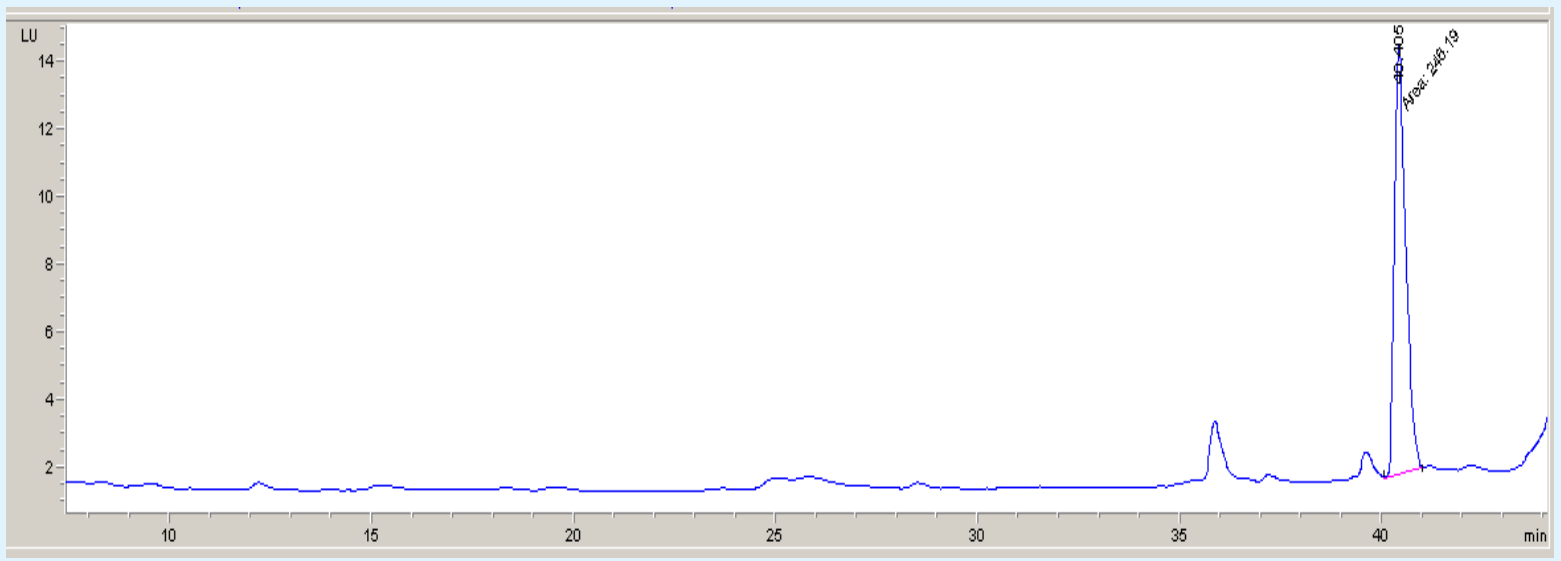

Figure 3: Chromatogram of leucine standard $(1000 \mu \mathrm{M})$.

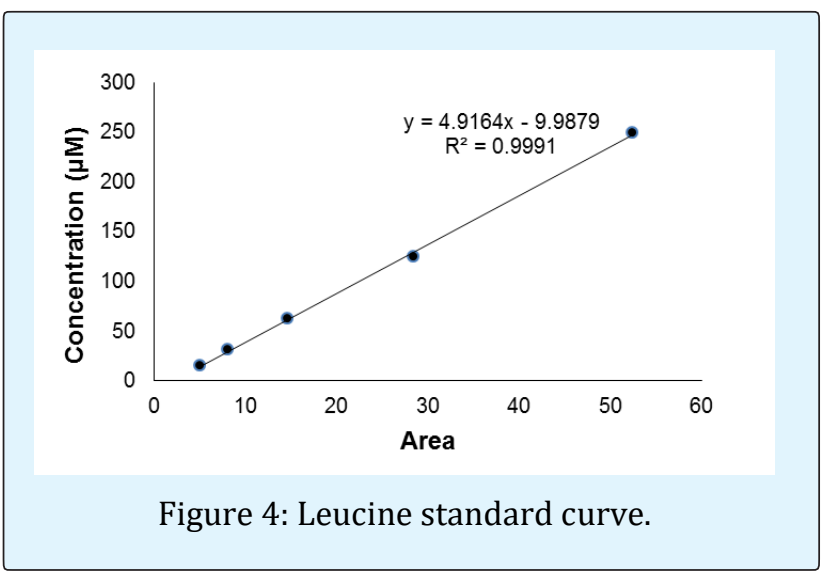

\begin{tabular}{|c|c|}
\hline Concentration $(\boldsymbol{\mu M})$ & Peak Area \\
\hline 15,625 & 5,06 \\
\hline 31,25 & 8,09 \\
\hline 62,5 & 14,65 \\
\hline 125 & 28,45 \\
\hline 250 & 52,43 \\
\hline
\end{tabular}

Table 3: Peak areas corresponding to leucine concentration $(\mu \mathrm{M})$.

\section{Isoleucine Standard Analysis}

It was determined that retention time for isoleucine was $39.66 \mathrm{~min}$. Chromatogram of isoleucine standard was shown in Figure 5.

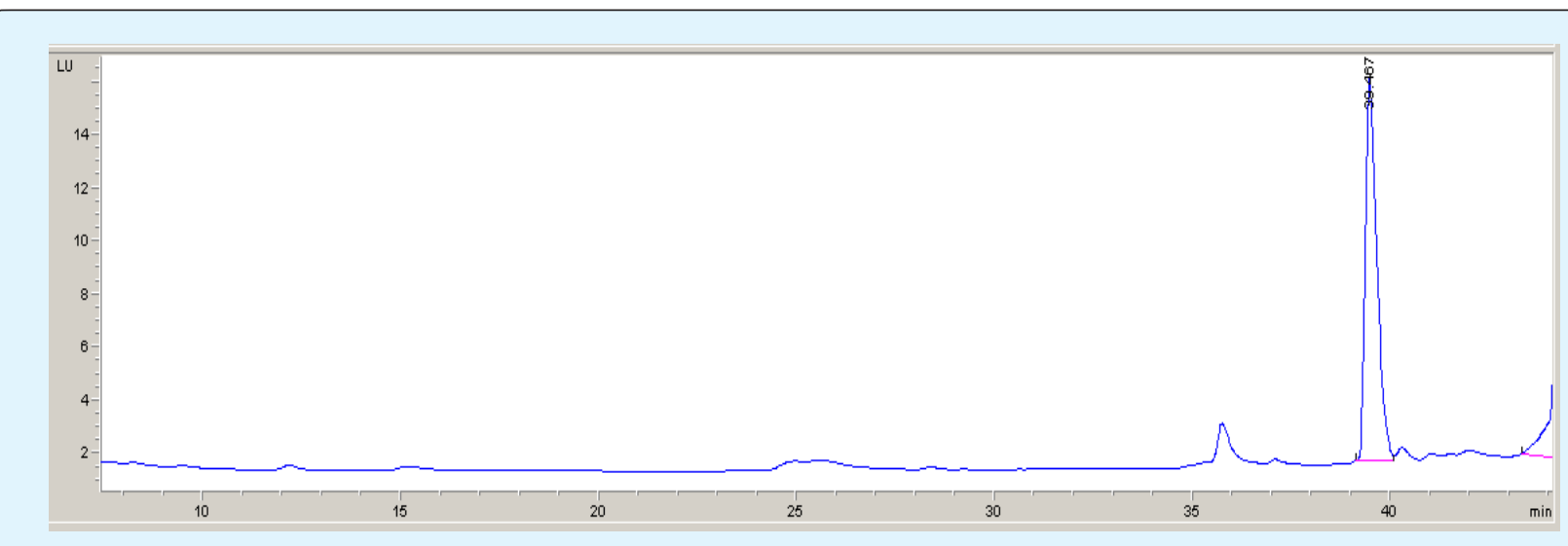

Figure 5: Chromatogram of isoleucine standard (1000 $\mu \mathrm{M})$. 


\section{International Journal of Biochemistry \& Physiology}

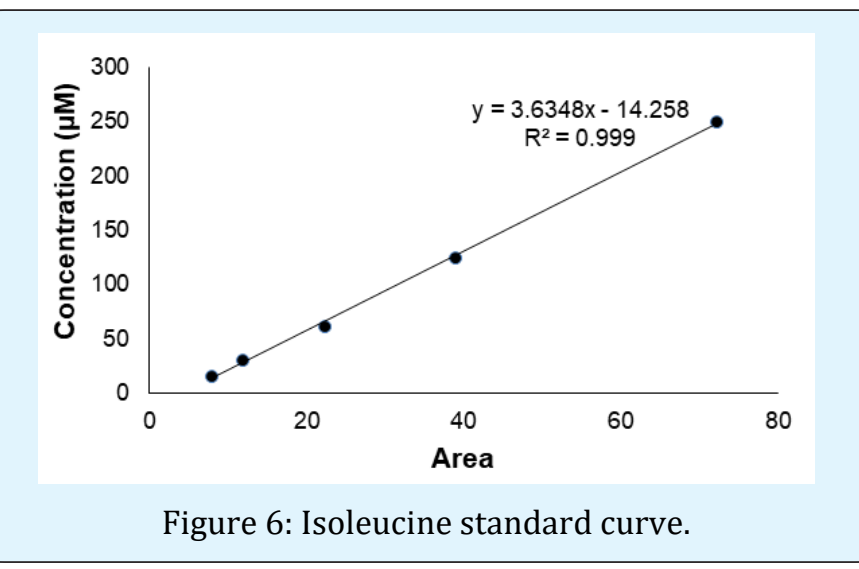

\begin{tabular}{|c|c|}
\hline Concentration $(\boldsymbol{\mu M})$ & Peak Area \\
\hline 15,625 & 7,77 \\
\hline 31,25 & 11,75 \\
\hline 62,5 & 22,25 \\
\hline 125 & 38,88 \\
\hline 250 & 72,22 \\
\hline
\end{tabular}

Table 4: Peak areas corresponding to isoleucine concentration $(\mu \mathrm{M})$.

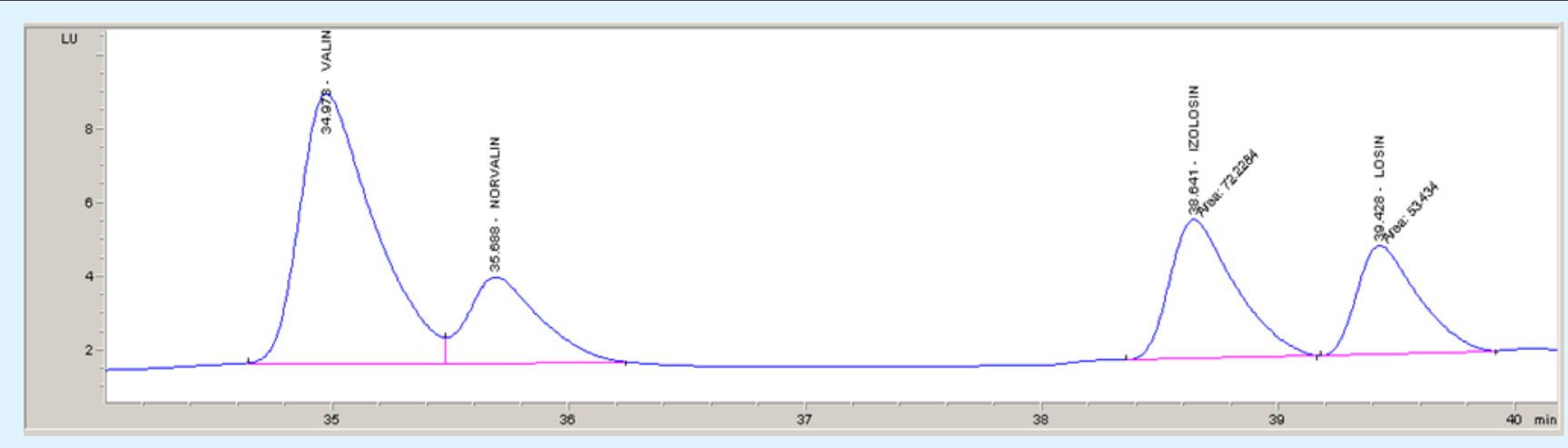

Figure 7: Chromatogram standard mix of isoleucine $(250 \mu \mathrm{M})$, leucine $(250 \mu \mathrm{M})$ and valine $(500 \mu \mathrm{M})$.

\section{Comparison of Valine, Leucine, and Isoleucine Levels}

Skeletal muscle growth depends on the ratio between muscle protein synthesis and protein degradation. Nutrition is also of great importance among factors affecting muscle metabolisms, such as hormonal status and exercise. It is known to increase the importance of proteins and amino acids especially in the nutrition of athletes. Studies suggest that during exercise, branchedchain amino acids (isoleucine, leucine, valine) are oxidized predominantly in skeletal muscle [10].

Colostrum is a protein-rich, immune and growth factor that promotes the growth and growth of the musculoskeletal system. Research on colostrum in recent years has been aimed at increasing athlete performance [11].

Mero, et al. in a study by athletes, 2 weeks after colostrum supplementation, muscle protein, and serum amino acid levels were analyzed. They observed that serum essential amino acid and branched-chain amino acid levels increased in athletes using colostrum, but there was no clear change in total protein balance [12].

Gleeson, et al. stated that exercise is a factor that increases protein use and changes the need of athletes. They showed that oxidation of branched-chain amino acid (BCAA) as an energy source increases in those who perform endurance exercises, but because of the glycogen in the environment, it suppresses the use of branchedchain amino acids for energy, in other words, it protects muscle proteins [13].

Zanetti, et al. investigated the physiological effects of these amino acids on muscle protein anabolism in volunteers with a mixture of amino acids enriched by branched-chain and aromatic amino acids. In the study, they showed that especially leucine increased the intracellular transport and protein synthesis [14].

Walker, et al. showed several reasons for the alteration of an amino acid profile in the analysis of plasma amino acids. These include sample collection, 


\section{International Journal of Biochemistry \& Physiology}

centrifugation, hemolysis, and changes in chromatographic analysis [15].

In our study, it was made a comparison between the experimental and control group by taking blood samples from all sportsmen at $0^{\text {th }}$ day (Table 5). Between the measurements of experimental and control group at $0^{\text {th }}$ day, while there is no significant difference at valine and leucine levels, it was seen that there is a significant difference at isoleucine levels. However, when it was looked at the total branched-chain amino acids (BCAA) levels, it was seen that there is no significant difference.

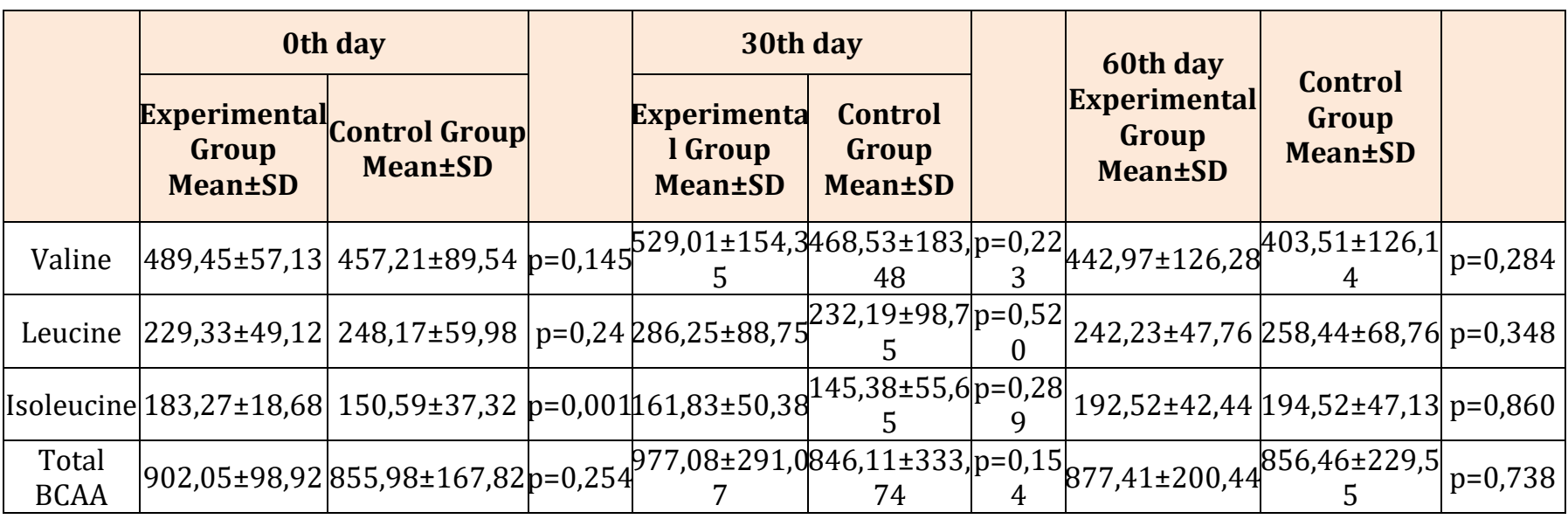

Table 5: Comparison of serum BCAA between experimental and control group $(* \mathrm{p}<0,05)$.

In this study, it was compared the branched-chain amino acid measurements of sportsmen using colostrum between each other at $0^{\text {th }}$ day, $30^{\text {th }}$ day and $60^{\text {th }}$ day (Table 6). For valine levels, it is not found any significant difference. For leucine levels, it was seen that there is a significant difference between $0^{\text {th }}$ day and $30^{\text {th }}$ day the measurements $(p=0,018)$. In the isoleucine levels, it was seen that there is a significant statistical difference between $0^{\text {th }}$ and $30^{\text {th }}$ day, similarly $30^{\text {th }}$ and $60^{\text {th }}$ - $d a y$ measurements $(p=0,044, p=0,005$ respectively). However, when it was evaluated the total BCAA levels among each other, it was not found any significant difference.

\begin{tabular}{|c|c|c|c|c|c|c|c|c|c|}
\hline \multirow[t]{2}{*}{$\mathbf{0}$} & \multicolumn{2}{|c|}{ Experimental Group } & & \multicolumn{2}{|c|}{ Experimental Group } & & \multicolumn{2}{|c|}{ Experimental Group } & \\
\hline & $\begin{array}{c}0^{\text {th }} \text { day } \\
\text { Mean } \pm S D\end{array}$ & $\begin{array}{c}30^{\text {th }} \text { day } \\
\text { Mean } \pm S D\end{array}$ & & $\begin{array}{c}0^{\text {th }} \text { day } \\
\text { Mean } \pm S D\end{array}$ & $\begin{array}{c}60^{\text {th }} \text { day } \\
\text { Mean } \pm S D\end{array}$ & & $\begin{array}{c}30^{\text {th }} \text { day } \\
\text { Mean } \pm S D\end{array}$ & $\begin{array}{c}60^{\text {th }} \text { day } \\
\text { Mean } \pm \text { SD }\end{array}$ & \\
\hline Valine & $\begin{array}{c}489,45 \pm 57 \\
12\end{array}$ & $\begin{array}{c}529,01 \pm 15 \\
4,35\end{array}$ & $\begin{array}{c}\mathrm{p}=0,2 \\
55\end{array}$ & $\begin{array}{c}489,45 \pm 57 \\
12\end{array}$ & $\begin{array}{c}42,97 \pm 12 \\
6,28\end{array}$ & $\begin{array}{l}\mathrm{p}=0, \\
102\end{array}$ & $\begin{array}{c}529,01 \pm 154 \\
, 35\end{array}$ & $\begin{array}{c}442,97 \pm 126 \\
, 28\end{array}$ & $\begin{array}{c}\mathrm{p}=0,06 \\
5\end{array}$ \\
\hline Leucine & $\begin{array}{c}229,33 \pm 49 \\
12 \\
\end{array}$ & $\begin{array}{c}286,25 \pm 88 \\
75 \\
\end{array}$ & $\begin{array}{c}\mathrm{p}=0,0 \\
18^{*}\end{array}$ & $\begin{array}{c}229,33 \pm 49 \\
12 \\
\end{array}$ & $\begin{array}{c}242,23 \pm 47 \\
76 \\
\end{array}$ & $\begin{array}{l}\mathrm{p}=0, \\
386\end{array}$ & $\begin{array}{c}286,25 \pm 88 \\
75 \\
\end{array}$ & $\begin{array}{c}242,23 \pm 47 \\
76 \\
\end{array}$ & $\begin{array}{c}\mathrm{p}=0,06 \\
3\end{array}$ \\
\hline $\begin{array}{l}\text { Total } \\
\text { BCAA }\end{array}$ & $\begin{array}{c}902,05 \pm 98 \\
92 \\
\end{array}$ & $\begin{array}{c}977,08 \pm 29 \\
1,07 \\
\end{array}$ & $\begin{array}{c}\mathrm{p}=0,2 \\
54\end{array}$ & $\begin{array}{c}902,05 \pm 98 \\
92 \\
\end{array}$ & $\begin{array}{c}877,41 \pm 20 \\
0,44 \\
\end{array}$ & $\begin{array}{l}\mathrm{p}=0, \\
575\end{array}$ & $\begin{array}{c}977,08 \pm 291 \\
, 07 \\
\end{array}$ & $\begin{array}{c}877,41 \pm 200 \\
, 44 \\
\end{array}$ & $\begin{array}{c}\mathrm{p}=0,22 \\
2\end{array}$ \\
\hline
\end{tabular}

Table 6: Comparison of the $0^{\text {th }}$ day, $30^{\text {th }}$ day and $60^{\text {th }}$-day serum BCAA levels of sportsmen at the experimental group. $(* \mathrm{p}<0,05)$.

\section{Conclusion}

In this study, it was determined that there was not any significant effect on serum branched-chain amino acid levels of sportsmen taking colostrum supplement in comparison to not taking any substance.
It was enlightened that the studies related to colostrum usage would be appropriate in different sports branches and various age groups considering especially criteria such as the immunity, regeneration, and performance of sportsmen. Factors such as times of colostrum usage, the various sports branches and the 


\section{International Journal of Biochemistry \& Physiology}

different food habits of the sportsmen involved in the research might have affected the results of this study.

\section{Acknowledgments}

This study was supported by The Scientific Research Projects Coordination Unit of Selcuk University (Project number: 14202017).

\section{References}

1. Pakkanen R, Aalto J (1997) Growth factors and antimicrobial factors of bovine colostrum. International Dairy Journal 7(5): 285-297.

2. Jaeger LA, Lamar CH, Bottoms GD, Cline TR (1987) Growth-Stimulating Substances in Porcine Milk. Am J Vet Res 48(10): 1531-1533.

3. Simmen FA, Simmen RC, Reinhart G (1988) Maternal and Neonatal Somatomedin-C Insulin-Like Growth Factor-I (Igf-I) and Igf Binding-Proteins during Early Lactation in the Pig. Dev Biol 130(1): 16-27.

4. Burrin DG, Davis TA, Ebner S, Schoknecht PA, Fiorotto ML, et al. (1995) Nutrient-Independent and NutrientDependent Factors Stimulate Protein-Synthesis in Colostrum-Fed Newborn Pigs. Pediatr Res 37(5): 593 599.

5. Thapa BR (2005) Health factors in colostrum. Indian J Pediatr 72(7): 579-581.

6. Donald R Henderson, Deborah R Mitchell (2000) Colostrum: nature's healing miracle: CNR Publications.

7. Zanker IA, Hammon HM, Blum JW (2000) Plasma amino acid pattern during the first month of life in calves fed the first colostrum at $0-2 \mathrm{~h}$ or at $24-25 \mathrm{~h}$ after birth. J Vet Med A Physiol Pathol Clin Med 47(2): 107-121.

8. Leah JM, Palmer T, Griffin M, Wingad CJ, Briddon A, et al. (1986) Urine amino acid analysis by HPLC in the investigation of inborn errors of metabolism. J Inherit Metab Dis 9: 250-253.

9. Blau N, Duran M, Gibson K (2008) Laboratory guide to the methods in biochemical genetics. Springer, pp: 53-73.

10. Blomstrand E, Eliasson J, Karlsson HK, Kohnke R (2006) Branched-chain amino acids activate key enzymes in protein synthesis after physical exercise. J Nutr 136(1): 269S-273S.

11. Buckley JD (2002) Bovine Colostrum: Does it Improve Athletic Performance. Nutrittion, 18(9): 776-777.

12. Mero A, Kahkönen J, Nykanen T, Parviainen T, Jokinen I, et al. (2002) IGF-1, IgA, and IgG responses to bovine colostrum supplementation during training. J Appl Physiol 93(2): 732-739.

13. Gleeson N, Bishop NC. (2000) Special Future for the Olympics: Effects of Exercise on the Immune Responses to Exercise by Carbohydrate, Glutamine and Antioxidant Supplements. Immune Cell Biol 78(5): 554-561.

14. Zanetti M, Barazzoni R, Kiwanuka E, Tessari P (1999) Effects of branched-chain-enriched amino acids and insulin on forearm leucine kinetics. Clinical Science 97: 437-448.

15. Walker V, Mills GA (1995) Quantitative methods for amino acid analysis in biological fluids. Ann Clin Biochem 32(P1): 28-57. 